\title{
THE MANUFACTURER'S FAILURE TO HALT TRADING STAMPS AS A BAR TO RELIEF UNDER THE FAIR TRADE LAWS*
}

FAIR trade laws ${ }^{1}$ permit the manufacturer of a trade-marked article to establish and maintain a uniform resale price, ${ }^{2}$ and provide that reselling below

*Colgate-Palmolive Co. v. Max Dichter \& Sons, Inc., 142 F. Supp. 545 (D. Mass. 1956).

1. Forty-five states have passed these acts. Only the legislatures of Vermont, Texas, Missouri and the District of Columbia have failed to enact fair trade statutes. $1 \mathrm{CCH}$ Trade REg. Rep. \ 3003 (1956). All the acts are similar, having been based on models provided by the National Association of Retail Druggists. The California act, after receiving approval in The Pep Boys, Manny, Moe \& Jack v. Pyroil Sales Co., 299 U.S. 198 (1936), became the model statute for at least sixteen states. The NARD later drafted a new model act which differed in some respects from the California act and has been adopted in at least nineteen states. See Report of the Federal Trade CoMiaission on Resale Price Matntenance xxvii-xxviii, 67-71 (1945) (hereinafter cited as FTC fair Trade Rep.) ; 1 Callaian, Unfair Competition and Trade-Marks $\$ 22.2$ (2d ed. 1950) ; Note, 52 HaRv. L. Rev. 284, 285 (1938). These statutes are frequently, and hereinafter will be, distinguished as "old type" and "new type." 1 Carlaran, op, cit. supra at 443.

In thirteen of these forty-five states, however, fair trading is not in full force. $1 \mathrm{CCH}$ Trade Reg. Rep. $\{3003$ (1956). The statutes succeed in permitting the manufacturer to maintain a uniform resale price only when they enable him to prevent price cutting by dealers who refuse to sign his resale price maintenance contracts. Fulda, Resalc Price Maintenance, 21 U. Cнг. L. REv. 175, 176 (1954). Statutory provisions of this sortnonsigner clauses-have been exempted from prohibition under the federal antitrust laws by the McGuire Act, 66 Stat. 632, 15 U.S.C. $\$ 45$ (1952). See Schwegmann Bros. Giant Super-Markets v. Eli Lilly \& Co., 205 F.2d 788 (5th Cir.), cert. denied, 346 U.S. 856 (1953) (McGuire held constitutional). But see Sunbeam Corp. v. Richardson, CCH Trade Reg. Rep. (1956 Trade Cas.) ff 68407 (W.D. Ky. July 16, 1956) (McGuire held unconstitutional). See also Report of the Attorney General's National ConiMitTeE to Study the ANTITRUSt Laws 149-52 (1955) (discussing prior legislation which failed to protect nonsigner clauses); Fulda, supra at 176-77; Note, 69 HARv. L. Rev. 316, 316-18 (1955). But state courts, free to pass on the constitutionality of fair trade legislation, have in recent months declared several of the acts invalid, at least as applied to nonsigners. See Olin Mathieson Chemical Corp. v. Francis, CCH Trade Reg. Rep. (1956 Trade Cas.) I 68463 (Colo. Aug. 27, 1956); General Elec. Co. v. American Buyers Cooperative, Inc., CCH TrADE REg. Rep. (1956 Trade Cas.) 爪 68341 (Ky. Cir. Ct. May 2, 1956); General Elec. Co. v. Wahle, CCH TRADE REg. Rep. (1956 Trade Cas.) If 68333 (Ore. April 18, 1956) ; Dr. G. H. Tichenor Antiseptic Co. v. Schwegmann Bros. Giant Super-Markets, CCH TRADE REg. Rep. (1956 Trade Cas.) ๆ 68400 (La. June 29, 1956) and cases cited in Notes, 65 Y YLE L.J. 235, 241 n.34 (1955); 69 HARv. L. Rev. 316,318 n.24 (1955). Other courts have gone beyond the nonsigner provisions in invalidating the acts. See General Elec. Co. v. Thrifty Sales, CCH TRADE Reg. Rep. (1956 Trade Cas.) If 68482 (Utah Sept. 22, 1956) (act held unconstitutional as to both signers and nonsigners); Benrus Watch Co. v. Kirsch, CCH Trade Reg. Rep. (1956 Trade Cas.) If 68319 (Va. April 23, 1956) (act in conflict with the state antitrust laws is inoperative). The arguments on fair trade constitutionality are discussed in Fulda, supra at 206-11; Notes, 4 J. Pub. L. 469 (1955); 69 HARv. L. Rev. 316, 349 (1955) ; 45 Ill. L. Rev. 378 (1950).

2. Under the "new type" statute only the trade-mark owner or a distributor specifically 
this price is unfair competition..$^{3}$ The most effective method for manufacturers and dealers to enforce their rights under the statutes is to obtain injunctions against dealers who engage in price cutting. ${ }^{*}$ Such violators, however, frequently defend against injunctions by showing that the plaintiff manufacturer has failed to enforce his resale price maintenance contracts against other dealers. ${ }^{5}$ Although the statutes do not explicitly recognize this defense, ${ }^{6}$ its

authorized may establish a fair trade price. Courts construing "old type" statutes have not been uniform in determining which persons in the distribution chain may fix fair trade prices. Cumpare Frank Fischer Merchandising Corp. v. Ritz Drug Co., 129 N.J. Eq. 105, 19 A.2d 454 (Ch. 1941) (wholesaler may establish price without consent of trade-mark owner), with Automotive Elec. Serv. Corp. v. Times Square Stores Corp., 175 Misc. \$65, 24 N.Y.S.2d 733 (Sup. Ct. 1940) (only owner of trade-mark may establish fair trade price) ; 1 Callman, op. cit. supra note 1 , at $\$ 24.1$ (b) ; Note, 52 HaRv. L. Rev. 284,287 (1938).

3. The cause of action established by these acts is in tort for unfair competition. Early in the history of fair trade litigation it was thought that the statutes created an equitable servitude in favor of the manufacturer, but under that theory a competing dealer would not have standing to enforce the restrictions. See 1 Callmax, op. cit. supra note 1, at $\$ 24.3($ a) ; Shulman, The Fair Trade Acts and the Law of Restrictive Agreements Affecting Chattels, 49 YaLe L.J. 607 (1940); Notes, 52 Harv. L. Rev. 284, 293 (1938); 25 Notre Dadre Law. 529 (1950). See also note 4 infra.

The "new type" statutes are aimed at preventing selling at less than a minimum price. The "old type" acts held that any selling "except at the price stipulated" is actionable. Because the forces of competition will not usually allow selling above the proscribed minimum, this distinction is not of consequence. See WeIger, The FaIr Trade Acts 41 (1938); 1 Callaran, op. cit. supra note 1 , at $\$ 24.1$ (c).

4. Enforcement against violators of fair trade laws is generally pursued by private litigation. Fulda, supra note 1, at 202; Note 65 YALE L.J. 235 (1955). Some states provide that government officials may take action to enforce these acts but the use of these powers has not been extensive. See Fulda, supra note 1, at 205-06; Notes, 65 YALE L.J. 235 n.3 (1955) ; 69 HaRv. L. Rev. 316, 352 n.200 (1955).

The statutes providing that violations are actionable by "any person injured thereby" have been construed to allow not only the manufacturer but also competing dealers, whether or not they have signed a fair trade contract, to bring enforcement suits. Port Chester Wine \& Liquor Shop, Inc. v. Miller Bros. Fruiterers, Inc., 281 N.Y. 101, 22 N.E.2d 253 (1939) ; Brosmeyer v. Pojlikoft, 39 Pa. D. \& C. 224 (C.P. 1940) ; Note, 65 Yale L.J. 235, 236 n.4 (1955). See also FTC Fair Trade Rer. 75; N.J. Stat. AnN. $\$ \$ 56: 4-6$ (Supp. 1956) (giving retailers a cause of action).

Although violations may entail liability in damages, injunctions are more usually suught because of the difficulty of establishing a causal relationship between defendant's price cuts and plaintiff's loss of sales. See Notes, 65 Y ALE L.J. 235, 236 n.4 (1955); 69 Hakv. L. REv. 316, 321, 340-43 (1955).

5. The defense of manufacturer's nonenforcement may not be available against enforcement suits by retailers. Stockman v. Wilson Distilling Co., 175 Misc. 314, 23 N.Y.S.2d 510 (Sup. Ct. 1940) ; if. Weissbard v. Fotter Drug \& Chemical Corp., 6 N.J. Super. 541, 69 A.2d 559 (Ch. 1949) (defense only if manufacturer's omissions amount to abandonment). But sie Pordes v. Lythe, 137 N.Y.S.2d 422 (Sup. Ct. 1955) (dealer's complaint must allege an active program of enforcement); Kline v. Davega City Radio Co., 168 Misc. 185, 4 N.Y.S.2d 541 (Sup. Ct. 1938).

Other defenses available to a price cutter, in addition to the unconstitutionality arguwent discussed in note 1 supra, are that he: sold only damaged goods; sold under court 
merit is obvious: as long as the manufacturer permits other dealers to cut, to enjoin one dealer from cutting prices would prevent the latter from meeting his competition. ${ }^{7}$ But frequently the courts discuss the defense of nonenforcement in different terms. By relying upon the clean hands doctrine and similar equity principles, courts suggest that any failure to pursue a reasonable and diligent enforcement program bars the manufacturer, ${ }^{8}$ without regard to the magnitude of the dealer's wrongdoing. Thus the courts have intimated that the defense of nonenforcement may protect a dealer who has cut prices more than was necessary to meet the competition fostered by the manufacturer's omissions.

The scope of the nonenforcement defense was thoroughly tested for the first time in the recent case of Colgate-Palmolive Co.v. Max Dichter \& Sons, Inc." Colgate brought proceedings to enjoin price cutting by a group of defendants who, the court found, had "consistently and willfully sold below [fair trade]

order; sold to a government agency; cut price by mistake; had no notice of fair trade contract; or purchased the goods before fair trade was initiated. See Notes, 69 Harv. L. Rev. 316, 320 (1955) ; 27 VA. L. REv. 518 (1941).

6. General Elec. Co. v. R. H. Macy \& Co., 199 Misc. 87, 103 N.Y.S.2d 440 (Sup. Ct.), appeal dismissed, 278 App. Div. 939, 940, 105 N.Y.S.2d 1003, 1001 (1st Dep't 1951); Caivert Distillers Corp. v. Nussbaum Liquor Store, Inc., 166 Misc. 342, 2 N.Y.S.2d 320 (Sup. Ct. 1938).

7. General Elec. Co. v. S. Klein-on-the-Square, Inc., 121 N.Y.S.2d 37, 54 (Sup. Ct. 1953) ; Automotive Elec. Serv. Corp. v. Times Square Stores Corp., 175 Misc. 865, 872, 24 N.Y.S.2d 733, 741 (Sup. Ct. 1940). Contra, National Distillers Products Corp. v. Columbus Circle Liquor Stores, Inc., 166 Misc. 719, 2 N.Y.S.2d 319 (Sup. Ct. 1938).

8. See, e.g., Wilson Distilling Co. v. Stockman, 11 N.Y.S.2d 51 (Sup. Ct. 1939) (plaintiff has not come into equity with clean hands) ; Hutzler Bros. v. Remington Putnam Book Co., $186 \mathrm{Md}$. 210, 46 A.2d 101 (1946) ("He who seeks equity must do equity"); Lentheric, Inc. v. Weissbard, 122 N.J. Eq. 573, 195 Atl. 818 (Ch. 1937) (same) ; Frank Fischer Merchandising Corp. v. Ritz Drug Co., 129 N.J. Eq. 105, 19 A.2d 454 (Ch. 1941) ("equality is equity" is fundamental to the fair trade act).

9. 142 F. Supp. 545 (D. Mass. 1956).

The Massachusetts fair trade law, Mass. ANn. LAws c. 93, $\$ \S 14$ A-D (Supp. 1955), under which this action was brought, is an example of the "old type" statute. FTC FAIR Trade ReP. 71. The constitutionality of the statute was upheld in General Elec. Co. v. Kimball Jewelers, Inc, 132 N.E.2d 652 (Mass. 1956).

In a few prior injunction suits a defense comparable to that in Dichter was raised. But in each of these cases the court determined that the practice allegedly tolerated by the manufacturer did not amount to a violation and that his acquiescence or nonenforcement could therefore be no defense. See Revere Copper \& Brass, Inc. v. Springfield Home Appliances, Inc., 1955 Trade Cas. If 67970 (N.Y. Sup. Ct. 1955) (plaintiff sold to premium houses); General Elec. Co. v. Two Guys from Harrison, Inc., CCH Trade REG. Rer. (1956. Trade Cas.) If 68458 (N.Y. Sup. Ct. 1954) (same); Westinghouse Elec. Corp. v. Charles, 1954 Trade Cas. II 67838 (N.Y. Sup. Ct. 1954) (plaintiff sold to clubs and initiated "soap coupon plan"); Sunbeam Corp. v. Central Housekeeping Mart, Inc., 1952-53 Trade Cas. \67379 (Ill. Super. Ct. 1952), reversed on other grounds, 2 I11. $2 \mathrm{~d} 543,120$ N.E.2d 362 (1954) (plaintiff's sales at less than fair trade prices at army posts no violation, but allegations that it tolerated sales to department store employees raises a triable issue); Sunbeam Corp. v. Klein, 32 Del. Ch. 65, 79 A.2d 603 (Ch. 1951) (plaintiff's toleration of sales on credit by defendant's competitors). 
prices."10 The defendants answered that by permitting other dealers to give trading stamps ${ }^{11}$ on the sale of fair traded items, Colgate had failed to pursue a reasonable and diligent campaign of enforcement and consequently was not entitled to an injunction. Many of Colgate's other dealers admittedly engaged in trading stamp practices. ${ }^{12}$ Individually they agreed with a trading stamp company that it would issue stamps to the dealer, and would redeem the stamps from the dealer's customers. ${ }^{13}$ The dealers than gave their customers one stamp for each ten cents of their total purchases. The customers accumulated the stamps until they had enough to exchange them at the stamp company's outlet store for merchandise valued at $2 x / 2$ percent of the customers' gross purchases. ${ }^{14}$ Colgate and intervening plaintiff Sperry and Hutchinson, a trading stamp company, argued that the practice did not constitute a reduction

10. 142 F. Supp. at 547.

11. Although trading stamps have been in existence since late in the 1800 's their largest gains have come about within the last five years. A Business Service Bulletin from the United States Department of Commerce estimates that stamps are saved by forty million American families, and surveys have indicated that in some areas $70 \%$ to $90 \%$ of the families are avid stamp collectors. An estimated 200,000 retailers throughout the country distribute these premiums to their customers, but the device has won unanimous support from neither consumers nor dealers. Dealers claim they are forced to use stamp plans to meet competition and that the stamps' cost exceeds their consumer attraction force. Many consumer groups argue that the stamps effect no bargain at all, but that ultimately the consumer foots the bill. Notwithstanding these challenges, as well as attacks by legislatures, the trading stamps are now big business. See U.S. News and World Report, Nov. 9, 1956, p. 112; What's Behind the Trading Stank Boom?, 21 CoNsumer Reps. 506 (1956); Comment, The Trading Stamp, 24 Tens. L. Rev. 557 (1956); New Haven Evening Register, Oct. 17, 1956, p. 47, col. 1; New York Times, Sept. 30, 1956, $\$ 3$, p. 1 , col. 2.

12. Though the operation of Sperry and Hutchinson is described here most other stamp companies seem to follow a similar pattern.

Some dealers allow a rebate to consumers who save cash register receipts. This plan has been construed by the courts to have the same effect as the trading stamp practice. Bristol-Myers Co. v. Picker, 302 N.Y. 61, 96 N.E.2d 177 (1950).

13. The absence of any agreement between the retailer and the trading stamp company is the most distinguishing feature of the cash register receipt program. In effect the retailer is creating his own trading stamps. This difference becomes minimal where several retailers combine to form a joint cash register receipts program; the customer obtains receipts from all member stores, and he may redeern them for the merchandise of any member he chooses. See Bristol-Myers Co. v. Picker, supra note 12.

14. $142 \mathrm{~F}$. Supp. at 548. The estimated value of a filled stamp book varies with whether the premium is figured at its full fair trade price, a discount price, or the wholesale price. Also the number of stamps needed to fill a book is not uniform among the stamp companies. Wiost of the commentators do not indicate the figures used to obtain their estimates. See Comment, 24 TENrs. L. REv. 557, 565-66 (1956) (book worth $\$ 2.00$, cost $\$ 120$ in purchases: $1.67 \%$ ); 21 Consumer Reps. 506, 509 (1956) (book worth $\$ 2.50$, cost $\$ 120$ to $\$ 150$ in purchases: $1.67-2.08 \%$ ) ; U.S. News \& World Report, Nov. 9, 1956, p. 112 (book worth $\$ 3.40$, cost $\$ 130$ in purchases: $2.61 \%$ ).

Under the cash register receipts plan the retailer may set his own premium rate. See Bristol-Myers Co. v. Picker, 302 N.Y. 61, 96 N.E.2d 177 (1950). Similarly a change in the effective rate of premiums from trading stamps can be made by the dealer's allowing 
in the purchase price of the fair traded item, but was merely an "innocuous discount for cash."15 And even if they were deemed to be a reduction in price, plaintiffs argued, trading stamps effected such a slight discount that the reduction should be disregarded. ${ }^{16}$

The court refused to grant a preliminary injunction until Colgate could show that it was taking appropriate steps to eliminate the trading stamp practice. In holding that trading stamps were condemned by the fair trade statute, the court relied upon a distinction familiar to accountants. It agreed with plaintiff that if the stamps were viewed as cash discounts they might be legal since this type of discount is not generally considered a reduction in the purchase price. But the court reasoned that because the entire operation resembled a quantity discount, ${ }^{17}$ trading stamps were also a "trade discount," which does, according to accepted accounting practice, reduce the purchase price. ${ }^{18}$ Furthermore, the discount, although small, nevertheless violated the

double stamps on purchases. See Weco Products Co. v. Mid-City Cut Rate Drug Stores, 55 Cal. App. 2d 684, 131 P.2d 856 (1942).

In some instances the stamps may be redeemed at the distributing retailer's place of business. See, e.g., Sperry \& Hutchinson Co. v. Margetts, 15 N.J. 203, 104 A.2d 310 (1954) ; Bristol-Meyers Co. v. Lit Bros., 336 Pa. 81, 6 A.2d 843 (1939).

Plans operating in some states allow the consumer to choose a cash refund rather than merchandise when redeeming the coupons. See Weco Products Co. v. Mid-City Cut Rate Drug Stores, supra. See also Kan. Gen. Stat. AnN. $\$ 19-2210$ (Supp. 1955) (stamps which do not show cash value on their face may be distributed only by licensed, heavily taxed outlets); WASH. REv. ConE $§ 19.84$ (1956) (prohibiting stamps unless cash value printed on each stamp).

15. 142 F. Supp. at 548.

16. Id. at 549 .

17. Quota discounts are based upon the volume of purchases and often can only be determined after a lapse of time. Paton, Accountant's Handbook 304-05 (3d ed. 1945). The court felt trading stamps fell within this category because a large number of stamps must be accumulated before the consumer obtains any value for them.

"Trading stamps have no value unless and until one fills a whole book. The average customer of a supermarket purchases about $\$ 4$ worth of goods at a time. He gets no 'cash' discount for this, alone. He earns his discount only by visiting $S$. \& $H$. licensees enough more times to spend $\$ 120 . "$

142 F. Supp. at 549.

"Besides the direct one I believe there is an additional psychological quantity discount. S. \& $\mathrm{H}$. redeems only in merchandise. The more attractive premiums require several books, and doubtless they are what most persons want. Relatively few would be satisfied with a one-book three dollar toaster."

\section{Id. at 549 n.5.}

18. Many courts have relied upon this analysis in determining whether trading stamps do effect a price cut but most of them have concluded that trading stamps are a legal cash discount. See, e.g., Weco Products v. Mid-City Cut Rate Drug Stores, 55 Cal. App. 2d 684, 131 P.2d 856 (1942); Nechamkin v. Picker, 189 Misc. 61, 67 N.Y.S.2d 60 (Sup. Ct. 1946) (citing Montgomery, Auditing Theory and Practice). The nature of a cash discount is widely disputed among accounting authorities. Those who maintain that cash discounts do not alter prices do so in order to distinguish between the financial and operational aspects of a business for purposes of evaluating management on a consistent 
statute; the court found the trading stamp operation so widespread as to be a potential cause of the retaliatory price cutting the fair trade laws were designed to prevent. Consequently, although it found that this prevalent use of trading stamps was not the cause of defendants' price cutting, ${ }^{19}$ the court held that Colgate had failed to pursue a reasonable and diligent enforcement program and was barred from injunctive relief. ${ }^{20}$

In sum, the court's interpretation of the defense of nonenforcement allows a manufacturer to fair trade his product only if he effectively forbids not only trading stamps but also any promotional schene which may be deemed equivalent to a price cut of any size. This view fails to relate the granting of an injunction to the two major goals of the fair trade laws: 1) protection of the small retailers, ${ }^{21}$ and 2) protection of the goodwill of the manufacturer's product. ${ }^{22}$ As to the first, relief should be denied if, on balance, an injunction would impair a defendant's competitive position or the interests of those dealers who observed fair trade restrictions. But neither of these harms would have followed from the granting of an injunction in Dichter. This is true even if, as some states hold, the trading stamp operation is a form of competition prohibited by the fair trade laws. ${ }^{23}$ Although trading stamps may conceivably lead to the costly retaliatory wars the statutes were enacted to prevent, only rarely

basis. The authorities who argue that cash discounts do adjust prices point out that these discounts are almost universally taken and no one expects to pay any more than the discounted price. This latter theory would seem more appropriately applied in the trading stamp situation. Pator, Accountant's Handbook 201, 304-05, 409-11 (3d ed. 1945) (collecting authorities).

For a discussion of whether accounting distinctions should govern the legality of trading stamps, see 63 Hanv. L. REv. 366 (1949). See also notes 23 and 32 infra.

19. 142 F. Supp. at 548 .

20. The court established that Colgate's toleration did not amount to unclean hands or waiver such that it would be pernanently barred from relief; Colgate could obtain an injunction against the defendants by opposing the heretofore tolerated violations.

After the original opinion Colgate adopted the court's view that the stamps in part reduced prices below the fair trade minimum. The court, satisfied as to the steps Colgate was taking to enforce against the trading stamp practice, granted a preliminary injunction against defendants. Colgate-Palmolive Co. v. Max Dichter \& Sons, Inc, 142 F. Supp. 545, 550 (D. Mass. 1956) (supplementary opinion).

As part of their proceedings against trading stamp violators Colgate brought suits against five supermarkets who issue stamps or cash register receipts in the Boston area. Colgate-Palmolive Co. v. Stop \& Shop, Inc., Mass. Super. Ct. Equity No. 71402-06, 71415 (1956). This case may be presented without a decision by the superior court judge to the Supreme Judicial Court of Massachusetts. This practice was followed in the case of Goneral Elec. Co. v. Kimball Jewelers, 132 N.E.2d 652 (Mass. 1956), which upheld the constitutionality of the Massachusetts fair trade act.

21. See Note, 65 Yale L.J. 235, $236 \mathrm{n.7}$ (1955) (collecting authorities).

22. See id. at 236 n.6 (collecting authorities).

23. The following courts have held trading stamps legal under the "old type" fair trade laws: Weco Products Co. v. Mid-City Cut Rate Drug Stores, 55 Cal. App. 2d 684, 131 P.2d \&56 (1942); Bristol-Myers Co. v. Lit Bros., 336 Pa. 81, 6 A.2d 843 (1939). Only New York has found trading stamps illegal. Bristol-Myers Co. v. Picker, 302 N.Y. 
will they be used as a device for aggressive price cutting. ${ }^{24}$ Defendants were not likely to be injured in the future by abnormal use of trading stamps, ${ }^{25}$ nor were they injured by past practices. For, in contrast to the small discount effected by the trading stamps, ${ }^{26}$ defendants' price cuts were often as much as fifteen to twenty percent. ${ }^{27}$ In this respect defendants' aggressive merchandising policies resembled those of discount houses, ${ }^{28}$ which normally rely upon

$61,68,96$ N.E.2d 177, 180 (1950) (dictum). No Massachusetts state court has as yet passed on the legality of trading stamps.

"For the purpose of preventing evasions of the resale price restrictions" the "new type" statutes specifically designate that gifts, coupons and combination sales are a violation of the act unless authorized by the fair trade manufacturer. FTC FAIR TrADE REP. \$2; 1 Callman, op. cit. supra note 1 , at $\$ 24.2(c)$. Manufacturers have successfully used these provisions to enjoin trading stamps. The Mennen Co. v. Katz, 1950-51 Trade Cas. If 62734 (Conn. Ct. C.P. 1950) ; Lambert Pharmacal Co. v. Roberts Bros., 1950-51 Trade Cas. If 62669 (Ore. Cir. Ct. 1950), rev'd on other grounds, 192 Ore. 23, 233 P.2d 25S (1951).

Other dealer practices have been alleged by the manufacturer to be indirect price cutting and injunctions have been requested. Miles Laboratories, Inc. v. Simon, $33 \mathrm{~F}$. Supp. 962 (E.D. Mich. 1940) (sales tax absorbed by dealer; injunction denied); BristolMyers Co. v. L. Bamberger \& Co., 122 N.J. Eq. 559, 195 Atl. 625 (Ch. 1937), aff'd per curiam, 124 N.J. Eq. 235, 1 A.2d 332 (Ct. Err. \& App. 1938) (discounts to dealers' employees; injunction granted); Bernhard v. Savall Drug Store, Inc., 82 N.Y.S.2d 122 (Sup. Ct. 1948) (gift to all persons who entered the store; injunction denied).

24. Trading stamps have lead to competition resembling a price war in only one known instance. That outbreak, in Denver, Colorado, in 1953, was halted when the stamp companies themselves convinced the retailers to stop the suicidal techniques. Business Week, Oct. 17, 1953, p. 54; Comment, 24 TENN. I. Rev. 557 (1956). The arrangement betwecn the stamp companies and the retailers may account for the lack of retaliatory actions. No stamps are sold to these stores; rather the retailers are licensed to issue stamps at the rate of one for every ten cents of sales. If the dealer attempts to compete by giving more than that number of stamps, his contract may be cancelled. See Sperry \& Hutchinson Co. Licensing Agreement para. Second (e), (f), Third, on file in Yale Law Library.

25. During the only notable instance of a trading stamp war, dealers were giving four stamps for each ten cent purchase. The discount effected by this step is at most $10 \%$. See Business Week, Oct. 17, 1953, p. 54; note 24 supra.

26. The Dichter court did not establish by what amount the trading stamps "cut price." At the most the reduction was $21 / 2 \%$, but the court agreed that part of this figure might be considered a legal discount for cash. $142 \mathrm{~F}$. Supp. at 549.

27. Id. at 548 .

28. Discount houses whose most rapid advances have come since the close of World War II, are considered one of the six major innovations in retail distribution since the Civil War. Conservative surveys estimate that the discount house has appropriated one third of the electrical appliance market. Most authorities are now convinced that discount outlets are a permanent part of the distribution system. See Palamountain, The Politics of Distribution 6 (1955) ; Alexander.\& Hill, What to do about the Discount House, Harv. Bus. Rev., Jan.-Feb. 1955, p. 53; Brecher, Discount Houses, 14 Consumes REPs. 343, 420, 469 (1949), 15 id. at 32 (1950); The Hard Sell Contes to the Discount House, Business Week, Oct. 13, 1956, p. 176. The great attraction of the discount house is reduced prices, but the consumer pays for these reductions, at least in part, by receiving fewer services from these dealers. Typically the discounting dealers offer less liberal credit terms, less choice in selection because of smaller inventories, and substantially no repair service. Trading stamps, on the other hand, are a form of non-price competition. Con- 
their own ability to evade the statute 20 in order to obtain large sales volumes at the expense of dealers who do maintain the manufacturer's established resale price. $^{30}$ Thus, since other dealers could regain volume lost to discount houses only at great expense and in violation of the statute, ${ }^{31}$ defendants' price cutting would harm other dealers much more than would the comparatively mild competition created by the use of trading stamps. ${ }^{32}$ Defendants, moreover,

sumers who are price conscious rather than service conscious will not be dissuaded from discount buying by an increase in services offered by competitors. See Consumer's Research Bulletin, May 1954, p. 2; 14 Consumer Reps. 469, 471 (1949); 15 id. at 32, 34-35 (1950); Trading Stamps, Bane or Boont, Business Week, May 19, 1956, pp. 43, 46. This traditional analysis may have to be revised, however, in the light of recent developments in the marketing economy. Price discounts have lost part of their attractive force in an inflationary period. Recent information indicates that discount houses have attempted to provide additional services for the consumer and some have even adopted trading stamps. See Sclling to an Age of Plenty, Business Week, May 5, 1956, p. 121; The Hard Sell Connes to the Discount House, supra; Trading Stamps, Bane or Boom, supra.

Defendants differed from the model discount house in that the entire operation was not controlled by a single management, but rather several concessionaires operated in one "factory outlet." 142 F. Supp. at 547 nn.1, 2.

29. The discount house uses an arsenal of techniques to avoid the effect of the fair trade statutes. They attempt to make detection of violations difficult by providing information on cut prices only to persons identified by cards, by using trade-in allowance and combination sale devices, and by refusing to give sales slips on fair traded merchandise.

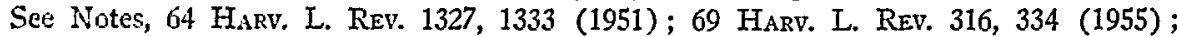
Fulda, supra note 1, at 203-05; 14 ConsuMER REPs. 420 (1949).

After violations have been detected and the fair trade manufacturer brings suit, the discounters again show their resourcefulness in the defenses they raise to these injunction actions. See 15 Consumer Reps. 218 (1950) and cases cited note 9 supra. Nor do injunctions cause any halt to the price cutting activities of these outlets. They usually pay, as a cost of doing business, contempt fines which are awarded to the manufacturer but which are so small as to be no deterrent to the dealer. See 14 Consumer REPs. 420 (1949); 15 id. at 218 (1950) ; Note, 64 HARv. L. Rev. 1327, 1336 (1951).

30. The fair trade laws have had little effect in halting discount house operations. See note 29 supra. Some authorities maintain that the presence of these laws aids the discount houses in appropriating sales away from dealers who are obligated to follow the statutes. See 14 Consurier REPs. 420,422 (1949); 15 id. at 218 (1950); Note, 64 Harv. L. Rev. 1327, 1332-33 (1951). But it is unfair to imply that the success of the discount house stems from this exploitation aspect alone. Usually the customer accepts lesser services, or the dealer is able to offer savings effected through reduced overhead. See Note, 69 Hanv. L. Rev. 316, 334 (1955). See also authorities cited note 28 supra.

31. At least one small town dealer has attempted to compete with city discount hauses. However this attempt was met by contempt proceedings, threats of jail sentences, and physical violence at the hands of local fair trade agents. See Fair Trade and Charles Hazohins, 15 Consuarer RePs. 220 (1950); 20 id. at 141 (1955).

32. Many retailers supporting price maintenance programs have adopted trading stamps as a competitive device. Available statistics indicate that while there may be as many as 10,000 outlets which can be classified as discount houses, there are 200,000 retailers who issue trading stamps. Alexander \& Hill, op. cit. supra note 28 , at 54; U.S. News \& World Report, Nov. 9, 1956, p. 112; Trading Stamps, Bane or Boom, Business Week, May 19, 1956, p. 43, 48. Although there is some authority for the notion that the statutes prohibit all price competition among fair trading dealers, see Bristol-Myers Co. 
could also easily protect themselves from any adverse effects trading stamps might have on their competitive position. Since Colgate permitted all dealers to give trading stamps on the sale of its products, defendants could match any discounts resulting from Colgate's acquiescence. ${ }^{33}$

Nor can the decision find support in the traditional rationale of fair trade legislation-to protect the goodwill of the producer of trade-marked items. ${ }^{24}$ Fair trading enables the manufacturer to obtain wide distribution by assuring his dealers an adequate profit margin; and, by permitting him to establish and publicize a uniform price, fair trade statutes enable the manufacturer to increase impulse buying and as a result consumer sales. ${ }^{35}$ Prolonged price cutting tends to reduce the number of outlets selling the product; dealers faced with a reduced or nonexistent profit margin will be reluctant to stock and sell the manufacturer's product, ${ }^{36}$ and the consumer, rather than buy on the spot,

v. Picker, 302 N.Y, 61, 96 N.E.2d 177 (1950), the better view seems to be that a limited amount of competition is permissible. Bristol-Myers Co. v. Lit Bros., $336 \mathrm{~Pa}$. 81, 6 A.2d 843 (1939); Fulda, supra note 1, at 201; Note, 64 Harv. L. Rev. 1327, 1332 (1951). Specifically, the statute should be construed to permit competition which does not injure the manufacturer's goodwill. Old Dearborn Distributing Co. v. Seagram-Distillers Corp., 299 U.S. 183, 193 (1936).

33. Moreover, by its continued acquiescence in the practice, Colgate might be said to have waived its right to enjoin use of trading stamps. Cf. Frawley Corp. v. Grosslight, 1954 Trade Cas. I 67681, at 69190 (Cal. Super. Ct. 1954) (plaintiff waived its right to enjoin dealers from giving employee discounts) (dictum).

34. Old Dearborn Distributing Co. v. Seagram-Distillers Corp., 299 U.S. 183 (1936). See also Gever v. American Stores, CCH Trade Reg. Rep. (1956 Trade Cas.) If 68404 ( $\mathrm{Pa}$. C.P. June 7, 1956). The harm to goodwill which fair trade purports to avoid is the sale of a reputable manufacturer's product as a "loss leader." See, e.g., Note, 64 HARv. L. REv. 1327, 1328 (1951). But fair trade accomplishes far more protection than the elimination of loss leader selling. For the statute adopts, as its method of protecting the manufacturer's goodwill, a general limitation on competition among dealers. BristolMyers v. L. Bamberger \& Co., 122 N.J. Eq. 559, 195 Atl. 625 (Ch. 1937) ; E. R. Squibb v. Charlines Cut Rate, 9 N.J. Super. 328, 74 A.2d 354 (Ch. 1950).

Commentators, arguing from the history of the struggle for fair trade legislation, have generally agreed that this interest of manufacturers is not the primary concern of the fair trade statutes but rather a camouflage for dealers who have sought and obtained exemptions from the antitrust laws to further their own monopolistic efforts. See PALAmountain, The Politics of Distributton cc. IV, VIII (1955); Fulda, supra note 1, at 201; Shulman, supra note 3; Bowman, Resale Price Maintenance-A Monopoly Problem, J. Bus. U. Chi., July, 1952, p. 141. This latter point of view has been expounded by a United States District Court while urging the Supreme Court to re-examine their approval of the fair trade acts in light of these arguments. The invitation was declined. Eli Lilly \& Co. v. Schwegmann Bros. Giant Super-Markets, 109 F. Supp. 269 (E.D. La.), aff'd, 205 F.2d 788 (5th Cir.), cert. denied, 346 U.S. 856, rehearing denicd, 346 U.S. 905 (1953).

35. See Corey, Fair Trade Pricing; A Reappraisal, Harv. Bus. Rev., Sept.-Oct. 1952, pp. 47, 51-52; Note, 69 HARv. L. Rev. 316, 327 (1955). Sales of consumer staple items, however, may not increase significantly because of impulse buying.

36. Note, 69 HARv. L. Rev. 316, 328 (1955). Such price cutting also risks the possibility that the manufacturer's product will be used as a loss leader. See note 34 supra. 
will prefer to shop for a better bargain. ${ }^{37}$ Since trading stamps do not lead to widespread price wars, ${ }^{38}$ the manufacturer may conclude that such competition does not constitute sufficient harm to his market to warrant the expense necessary to eliminate it, ${ }^{39}$ and may accordingly seek to create an exemption for trading stamp violations. ${ }^{40}$ To the extent that the act allows manufacturers to promote their product market, they should be allowed to carve out such exceptions.

The courts should, however, limit the manufacturer's freedom to create exemptions to the fair trade laws by following the familiar equity procedure of balancing hardships, ${ }^{41}$ thus considering the interests of manufacturers and dealers both. When a fair trading manufacturer who has acquiesced in some violations of the statute seeks to enjoin other violations, the courts should determine whether the greater harm would result from granting or from denying the injunction. ${ }^{42}$ This analysis would, for example, grant injunctive relief to a manufacturer who permits all his dealers to give discounts to their employees, a practice which does not affect their competitive positions, ${ }^{43}$ but

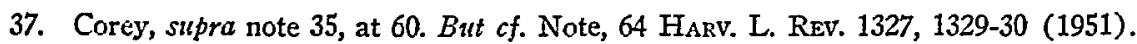

38. See notes 24 and 25 stipra.

39. Colgate had apparently made such a choice before the proceedings in this case. It had known of the existence of the trading stamp practice since 1954. See ColgatePalmolive Co. v. Elm Farms, Mass. Super. Ct. Eq. No. 71402, Stipulation p. 10 (1956).

40. Although the statutes provide that sales below the fair trade price are actionable with but three exceptions,-closing out discontinued merchandise, sale of damaged goods, or sale under court order-the manufacturer may allow more exceptions. Frawley Corp. v. Grosslight, 1954 Trade Cas. \ 67681 (Cal. Super. Ct. 1954). The "new type" statutes providing that trading stamps may be a form of violation, see note 23 supra, specifically provide that these devices may be permitted by choice of the manufacturer. 1 CaLluina , op. cit. supra note 1 , at $\$ 24.2$ (c).

A manufacturer wishing to allow his dealers to give trading stamps at a specified rate, should incorporate this exception into his fair trade contracts. See Westinghouse Elec. Corp. v. Charles Appliances, Inc., 1954 Trade Cas. $\int 67838$ (N.Y. Sup. Ct. 1954) (soap coupon plan integrated in contract) ; Burroughs Wellcome \& Co. v. Weissbard, 129 N.J. Eq. 563, 20 A.2d 445 (Ch. 1941), aff'd per curiam, 130 N.J. Eq. 605, 23 A.2d 396 (Ct. Err. \& App. 1942) (enforcing contract which excepted sales to doctors, dentists, etc.; distinguishing cases where the exception was not included in the contract). But cf. Frawley Corp. v. Grosslight, 1954 Trade Cas. $\{67681$ (Cal. Super. Ct. 1954) (exemption For discounts to dealers' employees need not be described in contract).

41. General Elec. Co. v. R. H. Macy \& Co., 199 Misc. 87, 103 N.Y.S.2d 440, 450 (Sup. Ct.), appeal dismissed, 278 App. Div. 939, 940, 105 N.Y.S.2d 1003, 1001 (1st Dep't 1951); Chafee, Coming into Equity with Clean Hands, 47 Mrrcr. L. Rev. 877, 1065, 1095 (1949). But sec Palmer v. Angert, 1950-51 Trade Cas. If 62830 (N.Y. Sup. Ct. 1951) (when parties both violate the act, equity will not grant relief to either).

42. See General Elec. Co. v. R. H. Macy \& Co., supra note 41 ; General Elec. Co. v. Federated Dep't Stores, Inc., 1955 Trade Cas. $\Uparrow 68098$ (E.D. Wis. 1955).

43. General Elec. Co. v. S. Klein-on-the-Square, Inc., 121 N.Y.S.2d 37, 49 (Sup. Ct. 1953); General Elec. Co. v. Monarch-Saphin Co., 80 N.Y.S.2d 419 (Sup. Ct., 1948); Frawley Corp. v. Grosslight, 1954 Trade Cas. If 67681 (Cal. Super. Ct. 1954). But see Bristol-Myers Co. v. L. Bamberger \& Co., 122 N.J. Eq. 559, 195 Atl. 625 (Ch. 1937), aff'd por suriam, 124 N.J. Eq. 235, 1 A.2d 332 (Ct. Err. \& App. 1938) (a manufacturer may enjoin his dealers from giving discounts to his employees). See also Shulman, supra note 3, at 622; 51 HARv. L. REv. 1305 (1938). 
would deny relief to a manufacturer who discriminates among his dealers. ${ }^{44}$ And it permits the manufacturer to single out the most flagrant violators for civil prosecution, thereby minimizing the cost and administrative burden of enforcing his fair trade program. ${ }^{45}$ Courts should recognize the need to protect consumers and deny injunctions to a manufacturer who fixes a sham fair trade price merely to give the consumer a false impression of the value of his product. ${ }^{46}$

The Dichter court would have obtained a better result by adopting this analysis. The court should have granted Colgate an injunction regardless of its acquiescence in the use of trading stamps, even assuming that their use violates the fair trade laws. For granting the injunction would have caused little harm to the defendants, ${ }^{47}$ and no harm to consumers, ${ }^{48}$ whereas denying

44. See Gillette Safety Razor Co. v. Green, 167 Misc. 251, 3 N.Y.S.2d 822 (Sup. Ct. 1938) ; James Heddon's Sons v. Callender, 29 F. Supp. 579, 580 (D. Minn. 1939) (dictum); General Elec. Co. v. S. Klein-on-the-Square, Inc., 121 N.Y.S.2d 37, 57 (Sup. Ct. 1953) (dictum) ; cf. Calvert Distilling Co. v. Brandon, 24 F. Supp. 857 (W.D.S.C. 1938) (allowances for quantity lots and delivery services do not constitute price discrimination). The manufacturer may also discriminate against dealers by product differentation. fair trading only selected products. This practice too should be held to bar the manufacturer from injunctive relief when the dealer can show he has been iniured. See Note, 69 Harv. L. Rev. 316, 345, 351-52 (1955).

45. Strong fair trade producers have been reported to have annual enforcement expenditures as high as one million dollers, and the prospect of so costly a duty has understandably dissuaded many manufacturers from entering a fair trade program. Sec Fulda, supra note 1, at 203; Alexander \& Hill, supra note 28 , at 62 ; Note, 69 HARv. L. REv. 316, 329 (1955).

Successful prosecution against the largest violators will usually minimize the cost of enforcement, for it will both deter aggressive price cutting by smaller dealers and placate those dealers who cut prices only to meet the competition of the "big fellow." General Elec. Co. v. S. Klein-on-the-Square, Inc., 121 N.Y.S.2d 37, 56 (Sup. Ct. 1953) ; see also Note, 69 Harv. L. REv. 316, 328-29 (1955).

46. See Note, 69 Harv. L. Rev. 316, 331-32 (1955) (describing the fair trade programs undertaken by sham enforcers in order to build an attractive discount house market). For other cases denying relief to a manufacturer whose laxness seemed to indicate a sham fair trade program, see Bathasweet Corp. v. Weissbard, 128 N.J. Eq. 135, 15 A.2d 337 (Ch. 1940) (manufacturer abandoned pricing system by marketing combination package which sold at a price less than the fair trade prices of its components); Wilson Distilling Co. v. Stockman, 11 N.Y.S.2d 51 (Sup. Ct. 1939) (manufacturer abandoned where he urged sellers to violate the maintained price restrictions); Kline v. Davega City Radio, Inc., 168 Misc. 185, 4 N.Y.S.2d 541 (Sup. Ct. 1938) (manufacturer denied relief where he had reduced prices to dealers but not the fair trade prices).

47. Defendant would not be forced to maintain prices in an area replete with price cutters. See also notes 23-33 supra and accompanying text. Nor can he claim a hardship, if he elects not to take advantage of a competitive practice approved by the manufacturer. Westinghouse Elec. Corp. v. Charles Appliances, Inc., 1954 Trade Cas. 167838 (N.Y. Sup. Ct. 1954). For examples of distinguishable situations where defendants could show hardship, see Kline v. Davega City Radio, Inc., supra note 46 (hardship would result if defendant were enjoined from meeting competition); Automotive Elec. Serv. Corp. v. Times Square Stores Corp., 175 Misc. 865, 24 N.Y.S.2d 733 (Sup. Ct. 1940) (same); General Elec. Co. v. Federated Dep't Stores, Inc., 1955 Trade Cas. $\int 68098$ (E.D. Wis. 1955) (same).

48. The statutes presume that the consumer does not achieve any true benefit from the 
the injunction harmed both the manufacturer and dealers. 49 The court forced Colgate to choose between abandoning fair trade or assuming the costly task of prohibiting its dealers from distributing trading stamps on its products. ${ }^{\text {so }}$ While the former choice would have denied dealers all fair trade law protection, the latter may enable discount houses to compete unfairly with impunity, for Colgate's enforcement task may be impossible to perform. ${ }^{51}$ Thus applied, the relative hardship test would give effect to the purposes of the fair trade laws. ${ }^{52}$ It is of course true that commentators have frequently

presence of price cutters in the market. "I cannot believe that in the long run the public will profit by the court permitting knaves to cut reasonable prices. ..." Holmes, J., dissenting, in Dr. Miles Medical Co. v. John D. Park \& Sons, 220 U.S. 373, 412 (1911); see also views of Drandeis, J., discussed in Comment, 66 YALE L.J. 69, 86-88 (1956), and WeIgEL, op. cit. supra note 3 , at 82 . But cf. authorities cited note 53 infra.

Miseover, conditioning the granting of relief to a manufacturer upon his eliminating the issuance of trading stamps on his fair trade products will not eliminate the stamps. Even if the manufacturer could effectively enjoin this practice, $c f$. note 51 infra, trading stamps would be eliminated on but those products sold under fair trade, and the evils that these stamps allegedly effect would continue with their use on non-fair traded items. Compare Rast v. Van Deman \& Lewis Co., 240 U.S. 342, 365 (1916) ("They [trading stamps] tempt by a promise of a value greater than that article and apparently not represented in its price, ... thus by an appeal to cupidity lure to improvidence."), with Sperry \& Hutchinson Co. v. Director of Division of Necessaries of Life, 307 Mass. 408, 421, 30 N.E.2d 269,276 (1940) (trading stamps have been in use so long that one is not apt to be deceived by their value, nor is there reason to believe that their users will resort to fraudulent practices).

And there is a more basic reason why the fair trade statutes should not be used as a device for attacking trading stamps. Fair trade laws do not seek to outlaw all forms of competition. See note 32 supra. Consequently, if the trading stamp operation is thought to be detrimental to consumers its condemnation should come from specific legislation and not urged under the auspices of fair trade. See 1 Callndan, op. cit. supra note 1 , $\$ 24.2$ (c), at 479 (arguing that fair trade is abused if used to outlaw merchandising methods which should be eliminated for reasons other than their effect on competition). Regulation of trading stamps generally is discussed in Wolff, Sales Promotion by Premiums as a Compctitive Practice, 40 Colum. L. Rev. 1174 (1940); 41 Iowa L. Rev. 265 (1956). See also N.Y. Times, Dec. 4, 1956, p. 65, col. 3 (any general regulation of the stamps might also lead to curbs on advertising, bargain sales, and other devices used to attract customers).

49. Even during the short interval between the original opinion and the time the injunction was granted appreciable damage to the manufacturer's fair trade structure might have oceurred. See Note, 69 Harv. L. Rev. 316, 329, 343 (1955). See also General Elec. Co. v. R. H. Macy \& Co., 199 Misc. 87, 98, 103 N.Y.S.2d 440, 451, (Sup. Ct.), appial dismissed, 278 App. Div. 939, 940, 105 N.Y.S.2d 1003, 1001 (1st Dep't 1951). For discussion of the harm to dealers see notes $28-31$ supra and accompanying text.

50. Cf. 24 U.S.L. WeEK 1193 (June 19, 1956).

51. The use of trading stamps is far more extensive than direct price cutting, and is engaged in by dealers who support fair trade. Also dealers will continue to give trading stamps on products of other manufacturers, whether fair traded or not, and the isolation of Colgate items may be a great burden for these retailers. See Alexander \& Hill, supra note 28, at 54; Bristol-Myers Co. v. Lit Bros., 336 Pa. 81, 6 A.2d 843 (1939); notes 11 and 32 supra.

52. The fair trade laws purport to protect not only the goodwill of the manufacturer's product, but also the interests of dealers and the consuming public. See General Elec. 
condemned these goals and the manner in which the fair trade statutes seek to attain them. ${ }^{63}$ Nevertheless, the courts should administer the act in a manner consistent with the legislative determinations of the soundness of these aims, ${ }^{54}$ and should in so doing determine how each decision may affect those interests the statutes seek to protect.

Co. v. R. H. Macy \& Co., 199 Misc. 87, 103 N.Y.S.2d 440 (Sup. Ct.), appeal dismissed, 278 App. Div. 939, 940, 105 N.Y.S.2d 1003, 1001 (1st Dep't 1951); Note, 65 Y YLE L.J. 235, 236 (1955) ; H.R. Rep. No. 1516, 82d Cong., 2d Sess. 11-12 (1952); H.R. Rep. No. 1292, 82d Cong., 2d Sess. 37-39 (1952).

53. Report of the Atrorney General's National Conmittee to Study the AntiTRUST LAws 149-55 (1955); Fulda, supra note 1, at 187 (collecting authorities), 201; Comment, 61 YaLe L.J. 381 (1952); Note, 64 HaRv. L. Rev. 1327 (1951); 20 Consuners Reps. 339 (1955); 14 id. at 230 (1949). But see Adams, Resale Price Maintenance; Fact and Fancy, 64 Yale L.J. 967 (1955); together with criticism in Herman, A Note on Fair Trade, 65 Yale L.J. 23 (1955), and reply in Adams, Fair Trade and the Art of Prestidigitation, 65 YALE L.J. 196 (1955).

54. Calvert Distillers Corp. v. Nussbaum Liquor Store, 166 Misc. 342, 344-45, 2 N.Y.S.2d 320, 324 (Sup. Ct. 1938) ; General Elec. Co. v. S. Klein-on-the-Square, Inc., 121 N.Y.S.2d 37, 42 (Sup. Ct. 1953); General Elec. Co. v. R. H. Macy \& Co., 199 Misc. 87, 91, 103 N.Y.S.2d 440, 445 (Sup. Ct.), appeal dismissed, 278 App. Div. 939, 940, 105 N.Y.S.2d 1003, 1001 (1st Dep't 1951). 